\title{
What is wrong with modern unjustified enrichment law in South Africa?
}

Jan-Louis Serfontein

$B A L L B B A$ (HONS) BA (HONS) LLM LLM

Lecturer in Jurisprudence and Legal History, University of the Witwatersrand

\section{OPSOMMING}

Wat Skort met Onreverdige Verryking in die Modern Suid Afrikaanse Reg?

Onlangse ontwikkelings op die terrein van onregverdige verryking in die Suid Afrikaanse reg het daarop gedui dat die Romeinse reg, wat die basis vorm van verrykings aanspreeklikheid, drasties getransformeer, en selfs totaal verander behoort te word ten gunste van 'n nuwe paradigma van vereistes. In dieselfde asem word voorgestel dat verryking nie meer onderdanig aan die ander obligations, te wete kontrakte- en deliktereg, gestel behoort te word nie, en dat dit 'n selfstandige derde been van die verbintenisreg behoort te vorm. Deur gehoor aan hierdie hervorming te gee sal egter impliseer dat die belangrike vereiste van verarming buite rekening gelaat kan word, en ook dat grondbeginsels van die verrykingreg, soos byvoorbeeld die reverdigheids- en die ekwiteitsbeginsel, verlore mag gaan. Die moontlikheid om die condictiones gedeeltelik of volledig te vervang word ook deur sommige kontemporêre skrywers ondersoek. Die belangrikste protagonis vir hierdie hervormings is Visser wat dit in sy boek Unjustified Enrichment uiteensit. In teenstelling hiemee wil hierdie artikel argumenteer dat die Romeinse reg 'n uitstekende en voldoende basis vorm vir die ontwikkelings wat op die terrein van die verrykingsreg voorgestel word. Die artikel wil verder argumenteer vir die behoud van die regverdigheids grondslag, soos ontwikkel deur die Romeinse-en gemene reg, as eerste beginsel van die verrykingsreg. Hiervoor word die regshistoriese metode aangewend. Hierdie metode toon nie die Romeinse reg tekste binne die konteks van die Corpus Iuris Civilis aan nie, maar eerder binne die konteks waarin hulle deur die klassieke juriste oorspronklik geskryf is. Die gevolg hiervan is dat die tekste veel meer kontekstueel uitgelê kan word. Sonnekus se boek Ongegronde Verryking in die Suid Afrikaanse Reg asook Du Plessis se boek The South African Law of Unjustified Enrichment word ook bespreek. Om die argumente af te sluit sal twee spesifieke probleme in die verrykingsreg oorweeg word. Ten eerste sal die afwatering van die wederkerigheids beginsel in die verrykingsreg, bespreek word, gevolg deur 'n analise van die verslapping van die par delictum reel in die Suid Afrikaanse reg. Daar word geargumenteer dat daar in beide hierdie gevalle meer indringende dringeder teoretiese herstelwerk aan die foutiewe interpretasiese van die howe gedoen behoort te word, eerder as om die Romeinse reg te probeer hervorm deur dit te vervang met regsbeginsels wat afkomstig is vanuit kontinentale gekodifiseerde stelsels wat onversoenbaar met ons reg is. Daar word ten slotte oorweging gegee aan die feit dat indien bogenoemde foute slegs deur wetgewing reggestel kan word, dit oorweeg behoort te word dat die gemene reg slegs hervorm kan word binne die fundamentele grondbeginsels van die onregverdige verrykingsreg.

How to cite: Serfontein 'What is wrong with modern unjustified enrichment law in South Africa?' 


\section{Introduction}

Unjustified enrichment law has always been the stepchild of the law of obligations in South African law. After the unfortunate judgment of Nortje $v$ Pool NO en ' $n$ Ander, ${ }^{1}$ where the South African Appellate division, by a majority of one, decided against accepting a general action for unjustified enrichment, the South African law of unjustified enrichment languished in a stagnant pool for more than 30 years.

This all changed when Peter Birks, the Regius Professor of Civil Law at Oxford, woke this area of the law from its slumbers when he suggested a fresh approach to the chaotic English law system of restitution by providing a more rational structure or taxonomy to bring the English common law system into the modern world. ${ }^{2}$ This made the English system much more workable and intelligible, and led to a worldwide reappraisal of unjustified enrichment law in both civil and common law systems.

South Africa was not unaffected. Recent developments in the South African law of unjustified enrichment have seen the rise of the view that the classical Roman law basis of enrichment should be radically overhauled and even discarded in favour of a new set of categories setting out how enrichment liability would arise; in the process, enrichment would be elevated to the status of being a third branch of the law of obligations, along with contract and delict. By doing this, however, the requirement of impoverishment would be abandoned, the primacy of the principles of equity and fairness would be lost, and the old Roman law condictiones, partially or altogether, thrown out. The main protagonist for this view is Visser, whose book on unjustified enrichment sets out this proposal. ${ }^{3}$ This article attempts to show that, on the contrary, the classical Roman law provides a perfectly adequate base from which to develop the law of unjustified enrichment. The paper will further consider the landmark case of McCarthy Retail $v$ Shortdistance Carriers 4 and how it represents a move towards the creation of a general action for enrichment liability in South Africa. Sonnekus and Du Plessis's scholarly works on unjustified enrichment law in South Africa, ${ }^{5}$ which both argue for the retention of the traditional approach to unjustified enrichment, will also be considered.

What must be emphasised at the outset is that the present state of our unjustified enrichment common law, and its development in recent years, can only be described as chaotic. This is primarily attributable to the meddling of our courts and the, at times, incorrect interpretations that they have given to common law principles. In view of this, the

1966 (3) SA 96 (A).

Birks Unjust Enrichment (2005) 39.

Visser Unjustified Enrichment (2008) 3-54.

CC 2001 (3) SA 482 (SCA).

Sonnekus Unjustified Enrichment in South African Law (2008); Du Plessis The South African Law of Unjustified Enrichment (2012). 
question must be raised whether it is not time to clean up our unjustified enrichment jurisprudence with clear and precise legislation.

The main thrust of the paper, however, is to indicate that major problems in our unjustified enrichment law exist and need to be addressed; attempting to tidy up the law through legislation in order to address these issues is certainly preferable to ripping out the law's historical roots and replacing them with Visser's new typology, which he has harvested from the codified German law. Specifically, two major problem areas will be considered. The first of these is the relaxing of the principle of reciprocity in the law pertaining to contracts and enrichment, and the second is the relaxation of the par delictum rule. As recently as November 2011, the Constitutional Court, through the majority decision by Moseneke DCJ in the case of Everfresh Market Virginia (Pty) Ltd $v$ Shoprite Checkers (Pty) Ltd, ${ }^{6}$ decided that it was desirable to develop the common law principles of contract law, and by implication unjustified enrichment, by infusing them with principles such as good faith and ubuntu. This paper will, therefore, argue that in keeping with this judgment, contractual reciprocity and the par delictum rule are the two areas of the common law that should be reformed rather than trying to adopt a liability matrix, and if a general action for unjustified enrichment is to be legislated, that these two areas should be reflected in such legislation.

To support this argument, leading cases concerning these two areas of law will be analysed to make the point that our courts have been compromising centuries of case law by ignoring these principles.

The first area of enrichment jurisprudence that should be reformed is the relaxation of the principle of reciprocity (pacta sunt servanda est). This is the foundational basis of any contract, and yet our courts have frequently deviated from it to enter the arena and, in the name of public policy or considerations of equity or pragmatism, altered the parties' contractual terms. Two of the most prominent of these cases, BK Tooling $(E d m s) B p k v$ Scope Precision Engineering (Edms) Bpk ${ }^{7}$ and Thompson $v$ Scholtz, ${ }^{8}$ will be returned to later in this paper.

The second area of enrichment jurisprudence that is in great need of reform is the relaxation of the in pari delicto potior est conditio possidentis ${ }^{9}$ rule when money or property has been transferred illegally or immorally and the condictio ob turpem vel iniustam causam is available as the remedy. This is an ancient remedy which was well known to classical Roman jurists. The rule was, according to Visser, ${ }^{10}$ De Vos, ${ }^{11}$

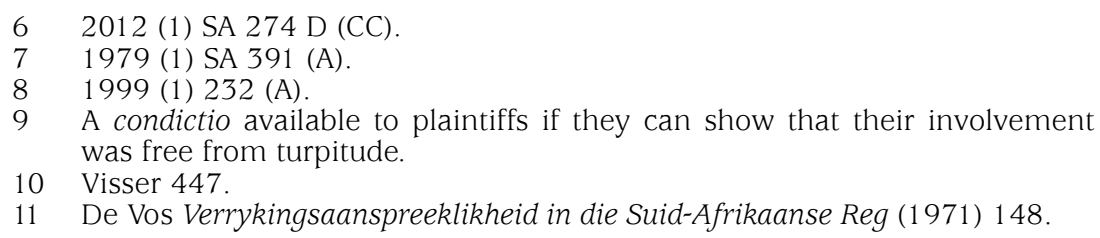

11 De Vos Verrykingsaanspreeklikheid in die Suid-Afrikaanse Reg (1971) 148. 
and De Wet $\&$ Van Wyk, ${ }^{12}$ very dogmatically applied in the RomanDutch law but relaxed in a string of controversial South African court decisions. ${ }^{13}$ This development was not universally followed by the courts. ${ }^{14}$ It is not only sound legal theory not to deviate from fixed and ancient legal principles, but it is bad practice to do so in the name of 'public policy' and, worse, to do so without any established criteria existing with which to judge when the relaxation may be applied. As a consequence, these deviations have been done casuistically, on a case by case basis, which can only lead to the exchange of legal certainty for instability. This dangerous tendency by our courts should rather be reformed than looking for a new place, in our division of law subjects, for enrichment law.

This paper argues that there is a far more pressing need to remedy these instances of laxity on the part of our courts than to start tinkering with the classical Roman civil law and replacing it with a totally new set of legal principles. If legislation is being considered to remedy these and many other uncertainties in enrichment liability, it should be done while respecting the foundational principles of enrichment jurisprudence.

In this regard, it should be emphasised that Roman unjustified enrichment law rested on the philosophical foundations of equity and fairness, as can be shown using a comparative legal-historical method to analyse the four central texts about unjustified enrichment from the Digest of Justinian, and more especially, to read them in their true contexts in the original works of the classical Roman jurists, using the Palingenesia of Otto Lenel. These four texts are two by Pomponius, in D: 12:6:14 and D: 50:17:206, and two texts - by Ulpian in D: 12:7:1:3 and Marcian in D: 25:2:25 - which restrict the wide application of Pomponius' texts by limiting them to unjustified actions or enrichment without cause. From this analysis it becomes clear that equity and fairness were always at the root of corrective unjustified enrichment. ${ }^{15}$

12 De Wet \& Van Wyk Die Suid-Afrikaanse Kontraktereg en Handelsreg (1978) 81

13 Jajbhay v Cassim 1939 AD 537; Visser v Rousseau 1990 (1) SA 139 (A); Klokow v Sullivan 2006 (1) SA259 (SCA).

14 The relaxation was not allowed in Mamoojee $v$ Akoo 1947 (4) 733 (N); Henry $v$ Banfield 1996 (1) SA 244 (D); Jorddan v Penmill Investments 1991 (2) SA 430 (E); Masekop v Maseko 19923 (SA) 190 (W); and Parbhoo v Spilg 19902 (SA) 398 (W)

15 Serfontein 'The Re-establishment of Equity and Fairness as the Founding Principles of Liability for Unjustified Enrichment in South African Law' 2012 Fundamina 56-61. See Serfontein 2012 Fundamina for an in-depth analysis of these four texts. 


\section{Birks: A New Typology for Unjustified Enrichment Worldwide: A Model for South African Legislation?}

For many years the English common law struggled to come to grips with the concept of restitution, and more recently with unjust enrichment. The common law, as we all know, is a magnificent creation of two thousand years of wisdom by the lawyers and, more specifically, the judges of England. As such it was based on piecemeal development without the benefit of an overarching theoretical framework that these and similar concepts enjoyed in the civilian tradition. The result was an ill-defined patchwork of casuistic jurisprudence based on the unsure footing of hundreds of cases that came before the English judges, where restitution was pleaded as the best remedy available. Most English academics and judges struggled on with this ragbag of jurisprudence rather than carrying out a comparative study to see how the civilian tradition coped with the same vexing questions, coming to a much more elegant solution by using the ancient condictiones of the Roman law and abstracting those principles into the concept of unjustified enrichment. Only one academic had the insight to do this - dragging the English common law into the twenty-first century by acknowledging the existence of unjust enrichment within the boundaries of restitution in the common law.

This academic was the late great Birks, Regius Professor of Civil Law at Oxford. After years of denial that there was a problem with the English law of restitution, Birks, towards the end of his very short life, wrote a work on unjust enrichment in which he explained the concept to the common law tradition. By suggesting such a fresh approach for the chaotic English law system of restitution, Birks provided a more rational structure that could bring the English common law system of restitution into the modern world. ${ }^{16}$ He made this startling advance by first of all differentiating between unjustified enrichment and restitution. He defined unjustified enrichment as: ${ }^{17}$

[T] he law of all events materially identical to the mistaken payment of a nonexisting debt. Such payment gives rise to a right to restitution. The law of restitution is the law of gain-based recovery.

Gain-based recovery is different from loss-based recovery, which is called 'compensation'. Restitution, although sharing characteristics of gainbased recovery with unjustified enrichment, is, however, not the same as unjustified enrichment. Birks goes further to distinguish between unjustified enrichment and restitution by indicating that contractual restitution is not unjustified enrichment. In English law this kind of restitution can be compared with 'mutuum' in Roman law and is distinct

16 Birks 39.

17 Idem 1. 
from unjustified enrichment. Another instance of distinction is the English restitution of gain-based recovery for wrongs. Birks quotes two well-known cases to illustrate this distinction - Boardman $v$ Phipps $^{18}$ and Attorney-General v Blake. ${ }^{19}$

After this ground-breaking distinction, Birks went on to structure the concept of unjustified enrichment in the common law, and insisted on the change from restitution to unjustified enrichment - from the morass of common law restitutionary jurisprudence to the clear and concise definition of unjustified enrichment in terms of the civil law. He emphasised that unjust enrichment was an independent event and not only a response, as in the restitution tradition. This made the English system much more workable and intelligible, and caused a worldwide reappraisal of unjustified enrichment law in both civil and common law systems.

This resulted in the reorganisation of the contemporary common law of unjustified enrichment around five core questions. These questions are: One, was there enrichment of the defendant, and two was the enrichment at the plaintiff's expense? If this is answered in the affirmative, then, three, was the enrichment of the defendant unjust, and if so, what right does the plaintiff have against such unjust enrichment? Lastly, one must ask which defences, if any, are available to the defendant in such circumstances. The similarities with Roman unjustified enrichment law are clear to see.

The first question that comes to mind if one studies the suggestions made by Birks, of course, is whether this typology will work as a basis for any suggested South African enrichment legislation? This question can be answered in the affirmative, with three qualifications. Firstly, the South African legislation should make provision for the acceptance of a general enrichment action in the proposed legislation. This will imply that the richness and diversity associated with the Roman law condictiones will disappear, but it will accommodate a much wider range of enrichment litigation and liability than before. Additionally, the principle of subsidiarity, usually associated with enrichment liability, will have to be abandoned. The typology suggested by Birks would only work if unjustified enrichment is seen as an independent event and not something dependent on an obligation, acting as a catalyst before it can come into operation. Finally, equity, the ancient basis of enrichment,

$1819672 \mathrm{AC} 46$ (HL). This is a case of restitution of gain-based profit based on a wrong from a breach of a fiduciary duty. A solicitor used his position, as an adviser to a trust, and his own money to substantially increase not only the trust's shareholding in a company, but also the profit in the company for the shareholders in the company.

1920001 AC 268 (HL). In this case, a defector from the British Secret Service wrote his autobiography and so breached the terms of his service contract. The Attorney-General successfully obtained an injunction to prevent the royalties from the book being paid to him in Moscow. This was not unjustified enrichment but rather gain-based restitution flowing from a wrong due to the breach of contract. 
would have to be abolished and enrichment would have to be recognised as an autonomous legal fact and not one designed specifically to address unjust or inequitable situations. Coupled with this is the fact that, logically, impoverishment would no longer be required in South African law.

Should all these requirements be met, it may be possible to use Birks' typology as a guideline in drafting South African enrichment legislation. However, the ideal would be to combine Birks' excellent typology with some of the present requirements of South African enrichment liability, such as subsidiarity and equity. Impoverishment is more arbitrary and, perhaps, could be sacrificed in the name of legal certainty when legislation is considered.

This radical departure from the common law by Birks not only caused a revolution in common law jurisdictions, but also in civil law jurisdictions - not even South Africa was spared the effects. This resulted not only in a string of dramatic judgments by our Supreme Court of Appeal, but also in no less than three textbooks being published after a drought of 30 years since the appearance of the standard work on the subject by de Vos in $1968 .^{20}$

\section{Daniel Visser on the Reform of Unjustified Enrichment in South Africa}

Visser states ${ }^{21}$ that, in South Africa, we should add a third branch to the traditional division of obligations, ${ }^{22}$ and this should be for unjustified enrichment. ${ }^{23}$ Through this book, Visser brought a similar revolution to South African jurisprudence as Birks did in the United Kingdom. The book 'draws on a rich and diverse legal heritage, and provides a

20 De Vos 11.

21 Visser 88-89.

22 Gaius, the famous second century teacher and jurist of Roman law divided obligations into three constituent parts. Contract, delict, and what he called ex variae causae figuris civilis iuris: G 3:119 a. Gaius divides obligations first into two main divisions, namely civil obligations - enforceable by action, and natural obligations - unenforceable by civil action but nevertheless with some legal effect. Later Gaius divided obligations into either contract or delict and finally 'a variety of figures from the civil law'. Three hundred years after this somewhat haphazard classification by Gaius, the great codification labours of Justinian I, under the careful eye of Tribonius, made the following classification of obligations: Contracts, delicts, quasi-contracts and quasi-delicts (Inst 3:13:2). Justinian's Institutes makes this seemingly arbitrary four-fold classification after stating somewhat more convincingly that the summa divisio of all obligations are either civil or praetorian. The figure of unjustified enrichment was placed either under ex variae causae figuris or quasi-contracts and quasi-delicts.

23 'This book remains faithful to that tradition in its attempt to give both an accurate description of, and a new start to, this third branch of the law of obligations' (Visser v). 
comprehensive and clearly structured exposition and an in-depth evaluation of the South African law of unjustified enrichment'. 24

The revolutionary nature of the work is to substitute the traditional Roman condictiones with a new organisational scheme for enrichment liability which, it would appear, wants to do away with impoverishment as a requirement for unjustified enrichment and suggests we move closer to a general action for unjustified enrichment in South Africa. Besides the loss of the requirement of impoverishment and the rich jurisprudence surrounding the application of the condictiones, the new system is not dependent on the rich equity philosophy that has always surrounded unjustified enrichment. ${ }^{25}$

Visser does not consider the traditional organisation of enrichment liability in South Africa compatible with a modern system of law. He finds the Roman law condictiones primitive, difficult, and almost impossible to understand. $^{26}$ He wishes to open up the actions for unjustified enrichment - even to the extent that South Africa would have a general enrichment action that removes the traditional requirements of the obscure Roman law condictiones. The vehicle he uses to achieve this can be found in the German law and, specifically, in the well-known Wilburg/ Von Caemmerer typology. ${ }^{27}$ He expands the primitive old categories into more open-ended or porous groups which are not based on equity, but rather on how the unjustified enrichment came about - in this, the influence of Birks on Visser's thinking can clearly be seen. ${ }^{28}$

In general, Visser wants enrichment liability to be divided into two main groups of acts which give rise to such liability. The first instance is the situation where the enrichment occurred due to a transfer of money, goods or services. The transfer, to establish unjustified enrichment liability, must be in error, under compulsion or protest, or must take place in terms of an illegal contract or an obligation that does not materialise - in short, a transfer sine causa. The second class of liability acts consists of instances which, in any other way, give rise to enrichment liability. These other acts include enrichment through encroachment and through outlays by another. Outlays by another can further be divided into expenditure, as a result of managing the affairs of another, and expenditure on the object of another. ${ }^{29}$

Visser is of the opinion that although this new typology is foreign to South African law, originating in German and not civilian law, it is preferable to the civilian model due to its better organisational structure

24 www.jutlaw.co.za (2008-04-30); advertising material for Visser Unjustified Enrichment on first publication.

25 Du Bois (ed) Wille's Principles of South African Law (2007) 1055-1057.

26 Visser 10-27.

27 Wilburg Die Lehre von der ungerechtfertigten Bereicherungnach Osterreichischem und Deutschem Recht. Kritik und Aufbau (1934) 113.

28 Visser 78-85.

29 Du Bois (ed) 1057. 
and because it will lead to a reduction in the large and diverse number of remedies currently available and, further, because the new organisational plan does not conflict with South African law. Although one can understand this argument, due to the masterful way in which Visser has integrated German models of unjustified enrichment law into South African enrichment law, the fact remains that German law is not the common law of South Africa in the same way that Roman-Dutch law is, and it would have been preferable had he found a fresh model of unjustified enrichment liability for South Africa within the confines of Roman-Dutch law.

Therefore, this paper argues that instead of looking to German, Scottish and English law to reform our historically-orientated law of unjustified enrichment, we should develop and, if necessary, extend the law in terms of our legal system's Roman-Dutch foundations. The great loss of Visser's new organisational matrix is that it moves away from the foundational principles of unjustified enrichment, namely equity and fairness. However compelling and organisationally attractive it might be to neatly gather unjustified enrichment into a third branch of obligations and then create a new open-ended matrix for enrichment liability, it simply cannot happen without taking cognisance of the origins and development of the foundations of unjustified enrichment. If one could change the organisational matrix of the civil law with the stroke of a pen - by creating an additional branch of obligations - why could one not then also create space for the law of damages as part of obligations? This wholesale tinkering with divisions created by Gaius and Justinian, and confirmed by Grotius, should only be altered under extreme circumstances. Legal certainty and confidence in millennia of judgemade law cannot simply be shifted aside in favour of a practical and organisationally attractive system developed in a continental legal system that has already been codified for many decades. In South Africa, the Roman civil law is still a primary source of our law, including our private law, and if we wish to be creative with our law of unjustified enrichment we should go back to the classic Roman law and not dabble with foreign systems.

In his book, Visser pays lip service to the foundational principles of enrichment and the principles of judicial law-making, and while he mentions and even analyses them thoroughly, his hidden agenda surfaces in descriptions such as 'our society must be responsive to modern commercial demands'. ${ }^{30}$ This is followed by a discussion of corrective and distributive justice and the role that the South African Constitution plays in these concepts. This, perhaps, is a jump too far. The constitution is loosely based on the values of dignity, equality and freedom. This is not the same as the concepts of equity and fairness described in the works of the classic Roman jurists. While one has to admit that there are similarities between the constitution and its underlying values and the foundational principles of unjustified

30 Visser 449-450. 
enrichment, the former is a political statement wishing to provide guidelines for the public law protection of rights, whereas the foundational principles of unjustified enrichment are essentially a balanced mechanism rectifying the excesses or shortcomings of private law - that is, the sacrosanct relationship of individuals within an obligation.

Many commentators are critical of Visser's interpretation of the views of Schutz JA in particular and, more generally, of his disjointed treatment of the decision in McCarthy Retail $v$ Shortdistance Carriers. ${ }^{31}$ Visser's views on these matters are scattered rather than focused, and suffer from admiration rather than critical analysis. Views on this precedent-breaking case are as varied as the views on the desirability of a general action for enrichment in South Africa. It is submitted that although the McCarthy Retail $v$ Shortdistance Carriers case is, as yet, the best example of the almost imperative need for a general enrichment action, this area of law should be developed incrementally and not twisted beyond recognition to accommodate a comfortable, modernist, matrix paradigm based on German law. Rather, it should be subject to the gentle bending and stretching of the ambit of the condictiones, as judges have been doing since the first century AD. Perhaps Schutz JA was correct when he held that: $^{32}$

A more daunting consequence of acceptance [of a general enrichment action] is the possible need for a re-arrangement of old-standing rules. Are the detailed rules to go and new ones to be derived from a broadly stated general principle? Or are the old ones to stand, and be supplemented by a general action which will fill the gaps? I would support the second solution.

To use German law and graft upon our uncodified Roman law tradition, an entirely new approach to unjustified enrichment liability is perhaps too much for our judges to digest. Despite the undiluted veneration one must have for Visser's magnum opus, one should heed the warning against enrichment imperialism from other commentators, who caution us to return to the well-worn traditional path of the condictiones jurisprudence. ${ }^{33}$

\section{Sonnekus: Creating a New Lexicography for Enrichment Liability in South African Law}

In a rigorous and scholarly work, Sonnekus introduced us to a first reworking of the unjustified enrichment landscape since the last appearance of the magisterial work of De Vos in the late sixties. ${ }^{34}$ The work by Sonnekus first appeared in Afrikaans, slightly ahead of Visser's

312001 (3) SA 482 (SCA).

32 Idem parr $488 \mathrm{~B}-\mathrm{D}$.

33 Lewis “Daniel Visser “Unjustified Enrichment”' 2008 SALJ 462-467.

34 De Vos 5-57. 
book. ${ }^{35}$ It would have been extremely interesting to see this commentator's views on Visser's new approach to unjustified enrichment. Sonnekus starts his work with the foundational premise that enrichment has a correctional function, where equity has, over centuries, been shaped and moulded to form a practical paradigm for restitution or enrichment liability. From this ancient foundation of enrichment liability, the principle of subsidiarity, or as Sonnekus calls it, an action of last resort, was developed. This principled view firmly places Sonnekus in the classic school of thought that enrichment cannot be a revolutionary 'third' independent arm of the law of obligations, as suggested by Visser. ${ }^{36}$ Most practitioners and academic commentators preferred the more familiar structure of Sonnekus' work, as opposed to the more speculative and unknown, as well as revolutionary, nature of Visser's matrix. ${ }^{37}$

Following the trend and methodology set by De Vos, the work of Sonnekus is also divided into two parts, the first being the general principles and generic requirements of enrichment, and the second being a discussion of the condictiones. Without being too imaginative, one can read into this division a particular view of enrichment, further confirming that Sonnekus may not be an enthusiastic supporter of the new matrix for founding enrichment liability suggested by Visser. He cleverly steers clear of the debate concerning the necessity of a general enrichment action by analysing the generic South African requirements for enrichment. ${ }^{38}$ Sonnekus, as a classicist and traditional scholar steeped in the civilian tradition, clearly does not support a transfiguration of the condictiones into a foreign template where the requirement of impoverishment might be abandoned. It should also be noted that Sonnekus is a leading authority in South Africa on Roman-Dutch as well as German law. Yet he is flexible about the evolutionary changing of the working of the condictiones. He does not consider enrichment liability to be cemented in the condictiones as the only key to liability and excluding all other modern possibilities, but Sonnekus does allow for public policy to sometimes deny a claim of the plaintiff or to redefine the defendant's obligations. ${ }^{39}$

As already alluded to, Sonnekus is one of the leading scholars on European law in South Africa and his work is distinguishable by the expert and self-assured manner in which he applies legal comparative

35 The Afrikaans version of this book (Sonnekus Onregverdige Verryking in die Suid Afrikaanse Reg) was published in 2007

36 Sonnekus 36.

37 Miller 'Unjustified Enrichment in South African Law' 2010 Advocate 49.

38 In this regard he spends a lot of time and space in discussing the apparent conflict between older case law such as Nortje v Pool NO 1966(3) SA 96 (A) and more recent developments in South African enrichment jurisprudence such as Buzzard Electrical (Pty) Ltd $v 158$ Jan Smuts Avenue Investments (Pty) Ltd 1996 (4) SA 19 (A); McCarthy Retail Ltd v Shortdistance Carriers CC 2001 (3) SA 482 (SCA); and Kudu Granite Operations v Caterna 2003 (5) SA 193 (SCA).

39 Sonnekus v-vi. 
methods to enhance the South African law of enrichment. One would expect the excellent use that he makes of continental systems, such as Dutch and German law, but what is utterly surprising about his approach, is the imaginative use of English law - applying it to empower South African jurisprudence. English law is the foundation of all common law systems world-wide not based on Roman civil law, which is the author's natural intellectual habitat. Sonnekus' comparative method proves that one can retain the traditional condictiones from Roman law as a basis for enrichment liability and yet make use of foreign legal systems to gently massage and sophisticate one's own system. The fact that Visser makes liberal use of the German system of enrichment to develop his new matrix for enrichment liability could therefore, by implication, be condoned by Sonnekus in the name of a greater unification of the law of enrichment.

Only two problematic theoretical objections remain against the largescale adoption of German or continental law into the South African law of enrichment; namely that we still stringently require impoverishment in our law of enrichment liability and, secondly, that modern German law is based on a codified system of law whereas in South Africa we rely on classical Roman civil law, which was not codified before the Corpus Iuris Civilis. These objections are not fatal, and should rather be seen as a warning against a wholesale adoption of codified foreign law into our uncodified system. There is no compelling reason for such integration due to the fact that the same, or even better, results can be obtained by a sensitive and intelligent application of Roman civil law principles.

\section{The Views of Du Plessis}

The latest addition to our unjustified enrichment jurisprudence is the book by Jacques du Plessis, The South African Law of Unjustified Enrichment, published early in $2012 .{ }^{40}$ This work follows the traditional approach to unjustified enrichment law in South Africa by first providing a meticulous and thorough analysis of the ancient principles of unjust enrichment. It presents the reader with two introductory chapters concerning the basic features and general requirements for liability in South African unjustified enrichment law. This is followed by a comprehensive and rigorous analysis of the five well-known condictiones in South African law. According to Du Plessis, however, these traditional pigeonholes of unjustified enrichment law do not always satisfy modern situations, and the unjustified enrichment jurisprudence ought to be expanded; if not to a full-blown general action, then at least to include some modern categories of unjustified enrichment liability. These include enrichment imposed on another and by taking from another, or infringement of another's rights.

40 Du Plessis 1-22. 
From a legal-political point of view, Du Plessis is of the opinion that our enrichment jurisprudence should be reformed and, to this end, he suggests that there are three avenues which one could go down to reform South African enrichment law. The first possibility suggested by Du Plessis is that of a subsidiary, residual general enrichment action. In terms of this route, the general enrichment action will only be activated if the traditional existing enrichment actions cannot be employed. This was the situation in South African and Roman-Dutch law before the Nortje $v$ Pool case and, according to Du Plessis, the preferred option expressly or tacitly held by the South African judiciary. The advantage of this route is that it will not be disruptive or create uncertainty in the legal traffic, but the disadvantage in the long term is that South African enrichment law will follow a dual-track approach which might eventually lead to confusion and misinterpretation.

The second route suggested by Du Plessis is the acceptance of a true general action detached from the traditional actions. In terms of this option, there will only be one general enrichment action, absorbing both the traditional grounds for enrichment liability and any new ground that may be created in modern South African law. This route is not favoured by Du Plessis as it would create legal uncertainty and also because such a course of action has not been without problems in the United States and various other continental jurisdictions. From a legal-historical perspective, this approach would be a disaster.

The final option available is a true general action which is still linked to the traditional actions. This link would be a reference to the rules and divisions of the traditional actions to inform the content of the general action - a true hybrid general action. The same complication exists for this route as for the second one - if it is not carefully managed by the judiciary, it may develop into a dual-track jurisprudence which will ultimately result in a melt-down of all the traditional actions into an unsatisfactory and cumbersome general enrichment action.

The analysis of Du Plessis should be welcomed. The only shortcoming is that he does not recognise the foundational principle of unjustified enrichment, namely equity and fairness. All the Roman authorities start off by emphasising this in the Digest. Pomponius (D: 50:17:206) states that according to natural law, it is equitable that nobody enriches himself at the expense of another. Paul (D: 12:6:15pr) talks of natural law as the source of unjustified enrichment and for Celsus and Ulpian (D: 12:4:3:7), natural equity is the guiding principle for unjustified enrichment. Celsus (D: 12:1:32) invokes the good and the equitable as the basis for unjustified enrichment actions. According to Paul (D12:6:65:4), fairness and equity is the foundation of unjustified enrichment principles and Papinianus (D: 12:6:66) calls it the good and natural. Good faith plays a role according to Africanus (D: 23:3:50), whereas Marcianus (D25:5:25) found his rule in the ius gentium. To ignore this when you are analysing routes to develop modern unjustified enrichment jurisprudence is a major shortcoming. 
However, it is the point of this paper to argue that despite the interesting developments that the authors above discuss, it is not the finding of new grounds for unjustified enrichment that is the most pressing reform that is needed - the judicial reform of the principle of reciprocity, or the exceptio non adimpleti contractus, and the application of the par delictum rule in the law of contract that poses far greater problems for modern South African unjustified enrichment jurisprudence. The only way to remedy this situation once and for all is, of course, through new legislation, but this would have to specifically ensure that the equitable nature of enrichment liability is preserved something that Visser does not provide for in his proposed new matrix.

\section{The Greater Problems with Enrichment Law}

In contrast to this return to the original sources and principles, and in the wake of cases such as Buzzard Electrical (Pty) Ltd $v 158$ Jan Smuts Avenue Investments (Pty) Ltd, ${ }^{41}$ McCarthy Retail Ltd $v$ Shortdistance Carriers ${ }^{42}$ and Kudu Granite Operations $v$ Caterna, ${ }^{43}$ Visser suggested a new matrix for unjustified enrichment, based on German law, which groups enrichment liability under three headings: Enrichment by transfer, enrichment through the invasion of rights, and enrichment due to outlays. ${ }^{44}$ The weakness of this scheme is that in its thrust to create a new typology for enrichment liability, it has lost the primacy of equity and fairness as founding principles of enrichment liability and it also necessitates the abandonment of impoverishment as an integral part of the requirements for unjustified enrichment. This was criticised by Lewis J of the Supreme Court of Appeal and contradicted, by implication, by other commentators such as Sonnekus, who suggested following the traditional way of applying the condictiones as the basis for enrichment liability.

What is the conclusion that can be drawn from all these arguments and viewpoints? Well, certainly, that a legal doctrine such as enrichment can never be removed from its foundational principles and be expected to stay the same. If you change equity and fairness as the first principles or foundations of enrichment liability, the whole structure will become less stable. Perhaps one should let sleeping dogs lie and accept the traditional condictiones as the primary basis for liability, possibly with a residual general action introduced by legislation, and look elsewhere to cure the ills of modern unjustified enrichment jurisprudence.

Although the above deliberations about a new matrix, or new routes, for unjustified enrichment liability in South African law are very interesting and challenging, one must ask the pertinent question whether

41 Buzzard Electrical (Pty) Ltd $v 158$ Jan Smuts Avenue Investments (Pty) Ltd supra $n 38$

42 McCarthy Retail Ltd $v$ Shortdistance Carriers supra $n 38$.

43 Kudu Granite Operations v Caterna supra n 38.

44 Visser 76-85. 
these considerations are the most important problems facing enrichment jurisprudence in South African law? Is a thorough analysis of the contemporary ills of enrichment law not higher on the agenda than a new matrix or alternative routes for the development of enrichment liability in South African law? One can immediately refer to two aspects of modern enrichment law that should rather be remedied than to invent an entire new matrix for liability. The first is the relaxing of the principle of reciprocity in enrichment jurisprudence, as was done in the case of $B K$ Tooling (Edms) Bpk v Scope Precision Engineering, ${ }^{45}$ and the second is the relaxation of the par delictum rule, as was done in the case of Jajbhay $v$ Cassim, ${ }^{46}$ when money or property had been transferred illegally or immorally, with the condictio ob turpem vel iniustam causam as remedy. ${ }^{47}$

The principles that govern the reciprocity of contracts, being pacta sunt servanda est, ${ }^{48}$ are the foundational basis of any contract and should they not be adhered to, the exceptio non adimpleti contractus ${ }^{49}$ would be available to the wronged party. ${ }^{50}$ The source and language of this wellknown dictum deserves comment. It comes from the Codex of the Emperor Justinian's codification, which implies that it was legislation, considered by Tribonius, worthwhile of being taken up in the codification of $527 \mathrm{AD}$. It is, therefore, not merely a useful practical saying but a piece of valid legislation contained in the Corpus Iuris Civilis. The language is also interesting - the form of the verb is a gerundive which indicates that it is imperative. During the last few decades, the courts have relaxed these principles in the name of public policy and equitable considerations without having regard to the first principles of the law of contract and enrichment. In both BK Tooling (Edms) Bpk $v$ Scope Precision Engineering (Edms) $B p k^{51}$ and Thompson $v$ Scholtz, ${ }^{52}$ the court violated the above principles to reach what they called an equitable and pragmatic solution.

Where one side of a reciprocal agreement undertakes to deliver before or together with the other party and subsequently fails to do so, the innocent party may withhold performance with the exceptio non adimpleti contractus. With part performance, the question of equity and fairness concerning what has been delivered and what has been used of the already delivered performance immediately comes to the fore. The courts, in the past, have ventured into the future to manipulate the

451979 (1) SA 391 (A)

461939 AD 537.

47 Zimmermann \& Visser Southern Cross Civil Law and Common Law in South Africa (1996) 542-549.

48 Pacta conventa omnimodo observanda sunt: (Valid) agreements are in all respects to be observed (Cod. 2.3.29.1).

49 The party claiming performance (instructor) under a contract can defend himself against the defaulting party (contractor) who did not complete or completed his performance unsatisfactorily with this exceptio by withholding his own performance (payment) until the other party (contractor) performs or performs satisfactorily.

50 De Wet \& Van Wyk Kontraktereg en Handelsreg (1992) 180.

$51 \quad 1979$ (1) SA 391 (A) 415.

521999 (1) (SA) 232 (SCA). 
contract price and order payment of a reduced price. The way in which the court does this is to take the original contract price and reduce it pro rata in so far as the innocent party has had benefit from the already performed part of the contract. This discretion of the court is subjective and not market-related and should be avoided at all costs. Visser, De Wet and Van Wyk consider this reduced price to be an enrichment action. Voet hints at an enrichment action being available to the performing party to claim back what has already been partially delivered to the other party. 53

The requirements to push the enrichment action into operation are: The contract must be cancelled to satisfy the requirement of sine causa, the obligations created by the contract must be extinguished, and a duty to return must be created. The enrichment action then falls, ex lege, on the party that has only performed in part, where that performance is being utilised to the benefit of the other party. The great benefit of this interpretation of the reciprocity of contract is that the solution is obtained via objective, established unjustified enrichment criteria and not subjective, discretionary judicial interference that may lead to judicial imperialism and corruption. Du Plessis is sceptical about using the enrichment action in these circumstances, and indicates that neither Voet nor the case law insists on this, even though he agrees that there are problems with quantification if an enrichment action is not utilised. ${ }^{54}$ De Wet \& Van Wyk $^{55}$ state that Voet does not envisage an unjustified enrichment action here because the calculation of the amount claimed must be done according to unjustified enrichment principles, which differ dramatically from contractual principles. This argument is sound, but not as an argument against using an enrichment action; rather, it should be seen as support for the use of an enrichment action instead of resorting to judicial discretion.

The relaxing of these principles by the judiciary may result in a pragmatic solution, but it tampers with the very fibre of our enrichment jurisprudence and should be discouraged. What the courts did in the $B K$ Tooling and Thompson $v$ Scholtz cases was to advantage the party who had breached the contract. This neither satisfies the requirements of equity or fairness, nor those of basic logic and theoretical purity. The relaxation of first principles to accommodate a situation where there is either partial performance and complete performance is impossible, or the parties are unwilling to complete performance, should urgently be addressed. The courts erred in deciding to intervene by ruling, in the one case, that a reduced contract price could be paid and, in the other, that there could be a remission of rent in a lease of land, and this should immediately be rectified rather than creating an entire new matrix for enrichment liability.

53 Voet Commentarius Ad Pandectas (1956) 19:2:401; translated into English by Gaine.

54 Du Plessis 94.

55 De Wet \& Van Wyk 181. 
The above violations of contractual principles, which could lead to claims for unjustified enrichment if the contracts were to be abandoned, did not find universal acceptance in South African law. Visser, ${ }^{56}$ the Law Commission $^{57}$ and Burrows ${ }^{58}$ are all in agreement that the relaxation of the strict rules of reciprocity will endanger the theoretical framework of both contractual and unjustified enrichment remedies.

A more recent case where the reciprocity of contracts was, once again, examined is in the case of Thompson $v$ Scholtz. ${ }^{59}$ Unfortunately, the Supreme Court of Appeal wasted this opportunity to rectify the situation concerning the enrichment claim that should have been allowed instead of once again applying judicial imperialism by entering the forum and the sanctity of contract by contracting on behalf of the litigating parties. This case further developed the rules of reciprocity of contract and the application of the exception non adimpleti contractus. Here, as in the BK Tooling case, the limits of the reciprocity of a contract, for work done by an independent contractor, had to be decided by the court where there was a near impossibility of mathematically calculating the cost of restoration. The seller of a farm, including the farmhouse, only gave full enjoyment of the entire property (the farm and the house) some five months after transfer of the farm - in other words, the seller enjoyed occupation of the farmhouse for five months after transfer of the property. Instead of solving this problem by finding that the seller was enriched with five months' rental (sine causa, as there was no lease contract in place), the court decided to grant an ancient remedy of remission of rent in a lease of land contract. This is a fiction, as there was never a lease contract entered into. The so-called 'remission' is calculated by the court on the vague and ill-defined basis of 'what is fair in the circumstances'. The court confirmed that they did not consider this to be an enrichment action, as was the case in Hauman $v$ Nortje, ${ }^{60}$ where the decision was supported by many commentators. ${ }^{61}$ Visser, however, is correctly of the opinion that an unjustified enrichment action should have been used in the Thompson $v$ Scholtz case. ${ }^{62}$

This slow erosion of one of the fundamental principles of the law of contract in South Africa is not reflected in comparative foreign jurisdictions. In the English common law such a move is frowned upon, ${ }^{63}$ and it is submitted that the current South African trend is incorrect and should be reversed at all costs. There should be a return to the strict

56 Visser 552-556

57 UK Law Commission Report on Pecuniary Restitution on Breach of Contract Number 121 (1983).

58 Burrows Modern Law Review (1984) 76-83.

591999 (1) (SA) 232 (SCA).

601914 AD 293

61 De Wet \& Van Wyk 182.

62 Visser 'Rethinking Unjustified Enrichment: A Perspective of the Competition between Contractual and Enrichment Remedies' 1992 Acta Juridica 231-236.

63 Burrows 79. 
purity of principle of reciprocity of contract, especially where the possibility of an enrichment action makes this possible.

The second area of enrichment jurisprudence that is in great need of reform is the relaxation of the in pari delicto potior est conditio possidentis rule, ${ }^{64}$ which means that where the plaintiff and the defendant are both tainted, then the position of the defendant is stronger and the plaintiff must fail when money or property has been transferred illegally or immorally. ${ }^{65}$ If the plaintiff is not tainted with dishonour, the condictio $o b$ turpem vel iniustam causam is available to him as the remedy for enrichment or restitution. ${ }^{66}$ From an illegal agreement there can come no obligation. The agreement is without force and neither of the parties can sue the other in terms of the contract ex turpi vel iniustam cause non oritur actio. Due to the illegal nature of the agreement, there is no contract (sine causa) and if there was performance, in terms of this void contract, there can be restitution in terms of the enrichment condictio $o b$ turpem causa. The exception remaining that where it would be scandalous for the plaintiff to perform, he or she will not be entitled to restitution or enrichment. ${ }^{67}$ The pari delicto rule is an ancient remedy which was well known to classical Roman jurists. ${ }^{68}$ According to Visser ${ }^{69}$ and De Vos, ${ }^{70}$ the rule was very dogmatically applied in Roman-Dutch law $^{71}$ and this was correctly followed in earlier South African case law, ${ }^{72}$ but was relaxed in a string of controversial South African court decisions. ${ }^{73}$ The most famous and well known of these cases is the case of Jajbhay $v$ Cassim.

This case considered whether, and on what grounds, a court could relax the par delictum rule when a party brings an action for the enforcement of a transfer of money or property in terms of an illegal agreement under the condictio ob turpem vel iniustam causam. Whereas the case centred on the par delictum rule (in pari delicto potior est conditio defendentis (possidentis)), it is expedient to outline the condictio ob turpem vel iniustam action since the decision considered the par delictum rule in reference to the condictio ob turpem vel iniustam action.

64 A condictio available to plaintiffs if they can show that their involvement was free from turpitude.

65 Aquilius A series of articles on 'Immorality and illegality in contract' SALJ $1941337 ; 194220 \& 194359$.

66 Visser 447-453.

67 D:12:5:3; D:12:5:4 \& D:12:5:8

68 Zimmermann Law of Obligations: Roman Foundations of the Civilian Tradition (1990) 847; D:12:5.; Codex 4:7.; Codex 4.9.

69 Visser 447

70 De Vos 23-163.

71 De Groot 'Inleidinge tot de Rooms Hollandse Rechtsgeleertheid' 3:1:41 and 3:30:17. Voet supra $n 53$ at 2:5:2.

72 United Providence Association Company v Vivian 1930 CPD 345; Affhauser v McLeod 1909 TS 827; Van Staden v Prinsloo 1947 (4) SA 843 (T).

73 Jajbhay 537; Visser v Rousseau 1990 (1) SA 139 (A); Klokow v Sullivan 2006 (1) SA259 (SCA); Afrisure CC v Watson NO 2009 (2) 127. 
The condictio ob turpem vel iniustam allows a party, to an illegal agreement, to sue for the return of anything that may have been delivered by way of performance under the illegal agreement on the basis of unjustified enrichment. ${ }^{74}$ This is only permitted in specific circumstances - the general rule is that a party to an illegal agreement cannot sue on the agreement as it is void. ${ }^{75}$ A successful institution of the condictio is dependent on satisfying the par delictum rule. ${ }^{76}$ This rule sets out that a plaintiff must demonstrate that their involvement in the illegal agreement is free from turpitude (that is, they did not act dishonourably by performing in terms of the illegal contract). ${ }^{77}$

In this case, the appellant, Jajbhay, was the registered holder of a licence which entitled him to occupy a stand at a location in Johannesburg. In contravention of the law in force, Jajbhay knowingly sub-let the property to the respondent, Cassim, who then took possession unlawfully. ${ }^{78}$ During the currency of the sub-lease, Jajbhay brought an action to the Transvaal Provincial Division ('TPD') seeking the ejection of Cassim from his property on the basis of the illegality of the sub-lease and the consequent unlawfulness of Cassim's occupation of the stand. ${ }^{79}$ The ejection application was refused by the TPD and Jajbhay lodged an appeal in the Appellate Division seeking the restoration of the possession of his stand. Before the Appellate Division, Jajbhay argued, in terms of the condictio ob turpem causam, that since he was the lawful occupier of the stand, and as the sub-lease was void on grounds of illegality, his claim to possession of the stand ought to be enforced since Cassim had no title to possession as sub-lessee. ${ }^{80}$

The court's approach was first to underline that since the sub-lease was not merely void but void due to illegality, further investigation was required before making a determination on Jajbhay's claim. ${ }^{81}$ The court pointed out that Jajbhay had to show that he "came into court with clean hands'; that is, that if he was a party to the illegality, he could not recover the possession he claimed. ${ }^{82}$ The court found that Jajbhay had indeed been party to the illegality that voided the sub-lease, applied the par delictum rule, and dismissed the appeal. ${ }^{83}$

In considering whether to apply the par delictum rule, the court stated that where it is shown that the rule's application will lead to injustice or where applying the rule may be contrary to public policy, the rule should not be rigidly enforced. ${ }^{84}$ Turning to English jurisprudence, the court

Du Bois (ed) 1064.

Jajbhay 541.

Ibid.

Idem 544

Idem 546.

Ibid.

Idem 547

Ibid.

Idem 548.

Idem 557

Idem 550 . 
noted that English law permits the non-application of the par delictum rule in circumstances where it would be in the public interest to prevent the enforcement of a contract entered into for an illegal purpose as well as in other exceptions extracted from decided cases. ${ }^{85}$ Specifically, English courts would not enforce the rule where a contract is made illegal by a statute which has the object of protecting a particular class of persons to which the party seeking the non-application of the rule belongs. ${ }^{86}$ The court highlighted a test in English law that was used to determine the enforcement of the par delictum rule. ${ }^{87}$ This test set out that where the plaintiff can show that his claim to recover possession was not connected to the illegal contract, or that recovery did not rely on the illegal contract, the rule would not be enforced. ${ }^{88}$ The court stated that its approach would avoid the listing of exceptions, as in English law, and narrowed its analysis to the suitability of this latter test to South African law. ${ }^{89}$ The court found this test to be of little utility, principally because it was designed for obligations that arose not from an illegal contract but from a contract collateral to an illegal contract. ${ }^{90}$ Jajbhay's claim fell squarely within the enforcement of obligations arising from the illegal contract concluded with Cassim. ${ }^{91}$ In addition, the court rejected this test on the basis that it could lead to confusion and uncertainty in its application in South African courts. ${ }^{92}$ This was due to the fact that the test allowed for an inordinately wide interpretation of what reliance on, and connection to, an illegal contract could mean. Although the court recognised that the par delictum rule ought not to be enforced rigidly, it, nonetheless, left the determination of the circumstances in which it would not be enforced to the circumstances particular to specific cases and considerations of public policy.

This development was not universally followed by the courts ${ }^{93}$ or the commentators on this issue. ${ }^{94}$ Du Plessis defends this broad and vague test, followed in the Jajbhay case, by indicating that the legal certainty so secured comes at a high price, where the tainted transferor is not able to claim either performance or restitution. ${ }^{95}$ Despite this viewpoint, it is sound legal theory not to deviate from fixed and ancient legal principles and bad practice to do so in the name of 'public policy' and, worse, to do

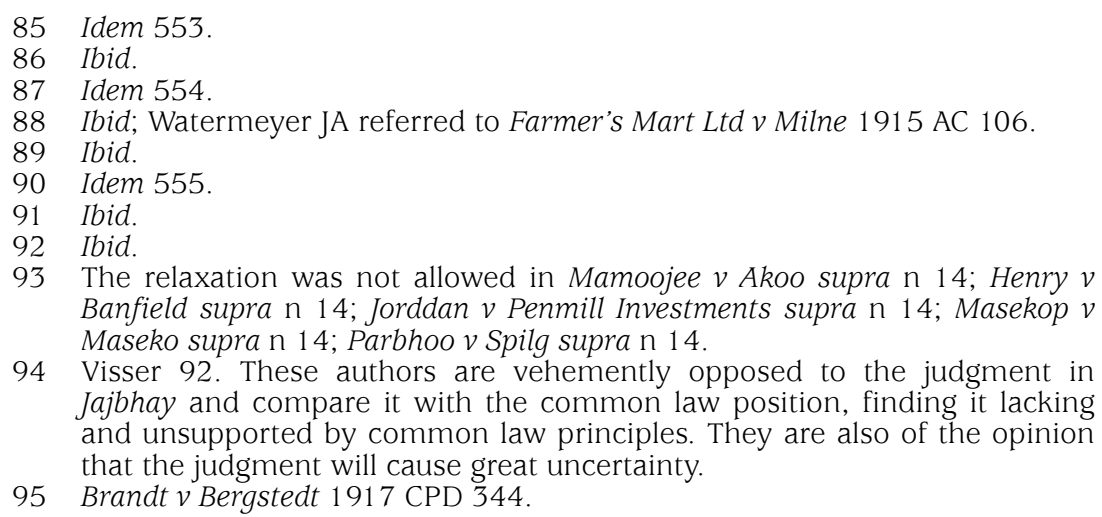


so without any established criteria existing with which to judge when the relaxation may be applied. As a consequence, these deviations have been done casuistically, on a case by case basis, which can only lead to the exchange of legal certainty in our common law for instability.

As indicated above, our courts are fortunately not in universal agreement about when, how and if the par delictum rule should be relaxed. Two examples of this can be found in the cases of Mamoojee $v$ Akoo, and Henry $v$ Branfield. In the earlier case, there was a sale of immovable property and the price of the property was dishonestly reflected to be lower than the price actually paid in order to avoid a, then, applicable fixed property profit tax. The court found the agreement illegal and void.

The more recent case concerned a fraudulent agreement between a Zimbabwean citizen and a South African citizen to avoid exchange control between their respective countries when the Zimbabwean emigrated to South Africa. The court dismissed the plaintiffs action as it considered this case to be a contravention of South African exchange control measures. The agreement, therefore, was null and void and payment could not be reclaimed. The pari delicto rule should not be relaxed if it places the plaintiff in a better position than where the agreement was sound and proper, or as encouragement to benefit from dishonest agreements. In Jordan $v$ Penhill Investments, ${ }^{96}$ a lease contract was entered into in contravention of the Group Areas Act. ${ }^{97}$ The landlord applied for eviction of the unlawful tenants due to arrear rent which was in excess of the allowable rent under the Rent Control Act. ${ }^{98}$ The unlawful tenants replied that they are not in arrears as they had paid all monies payable under the Rent Control Act. The plaintiff reacted by saying that the agreement was an offence and, as such, was void and not subject to the Rent Control Act. The tenants then invoked the par delictum rule, which placed them in the stronger position and prevented the plaintiff from evicting them. The plaintiff then asked the court to relax the rule which, correctly, was refused.

Du Plessis has designed a six-point matrix of criteria that the courts may in future take into consideration when considering a relaxation of the pari delicto rule. ${ }^{99}$ He starts off by stating that discretion will be exercised in accordance with the extent to which performance has taken place. Partial performance, in most cases, will create an enrichment action which will call for the relaxation of the rule. With full performance, where the plaintiff has returned what he had received, the defendant will be enriched. In the second instance, the nature of the performance may also be relevant. The third consideration may be the interest of third parties, and the fourth is the relative degree of fault of the parties. The

961991 (2) SA 430 (E)

9736 of 1966.

9880 of 1976

99 Du Plessis 206-207. 
fifth criterion is the relationship between the parties, and the sixth allows for different degrees of relaxation of the rule depending on the purpose of the prohibition.

As is abundantly clear from this contrived matrix of criteria, that the courts might take into consideration when relaxing the pari delicto rule, is that the more you try to theorise about the relaxation of the rule, the deeper into a morass of uncertainty you sink. The law of unjustified enrichment should be brought back to the common law approach to the problem, in that no relaxation to the pari delicto rule should be tolerated. If the plaintiff and the defendant are both guilty of illegal or immoral conduct in coming to an agreement, that agreement is null and void and no recovery can be made or enrichment action instituted.

A contrary view is that of Eiselen, ${ }^{100}$ who argues that moral turpitude should not play a role in sophisticated private law and enrichment law structures whatsoever. According to Eiselen, civil claims have lost their penal character, as this aspect is usually taken care of by criminal law. It is not the task or character of private or enrichment law to punish offenders or to protect public policy or morality - additionally, it would be preferable if the pari delicto rule were abolished altogether. He believes this would assist in developing our enrichment law to a greater level of sophistication, and further pave the way to the acceptance of a general enrichment action. Unfortunately, the courts have chosen to ignore this progressive solution advocated by Eiselen and continue to tamper with the principles of the common law instead of suggesting the replacement of an unworkable model with modern enrichment legislation where the par delictum rule will play no role. ${ }^{101}$

The dangerous tendency by our highest courts to relax the pari delicto rule should rather be reformed than to look for a new matrix and place for enrichment law in our division of obligations. The only sure way of attending to this is by drafting new legislation which removes the common law as the only source of enrichment liability, but ensures that all the foundational principles of enrichment liability are retained in that legislation.

\section{Conclusion}

The object of this article is to plead for a return to first principles in unjustified enrichment jurisprudence. These first principles were expounded by applying a legal-historical method to analyse the four famous texts from the Digest concerning unjustified enrichment. To contextualise these texts in their original settings, the work of Otto Lenel was used to look at the surrounding texts in the original classical Roman law textbooks. From this it became abundantly clear that equity and fairness were always at the root of corrective unjustified enrichment. This

100 Eiselen \& Pienaar Unjustified Enrichment A Casebook (2008) 94-95.

101 Klokow v Sullivan 2006 (1) SA 259 (SCA). 
approach was challenged in a new book on enrichment by Visser, in which he advocated for not only a new organisational matrix to establish unjustified enrichment, but also for enrichment to become an independent third branch of obligations next to contract and delict. This was criticised by Carole Lewis J and, by implication, Sonnekus. The final conclusion, to which this study then came, is that there are many other more pressing reforms needed in unjustified enrichment jurisprudence, where first principles have been violated, than the reforms suggested by Visser. Specifically, the relaxing by South African courts of the principle of reciprocity (pacta sunt servanda est) and of the par delictum rule, in the law pertaining to contracts and enrichment, undermine the foundations of our legal system. This is because the dogma and system of unjustified enrichment cannot function if the basic principles of that branch of law are agitated because it is based not on legislation, but on our common law.

It seems that the only way forward is to legislate the principles of unjustified enrichment into modern legislation. The strict proviso for such legislation is, however, that the subsidiary role of enrichment liability is strictly preserved, the requirement of impoverishment is abandoned, and equity is recognised as the foundational basis of unjustified enrichment law. 